\title{
Pengaruh Prinsip-Prinsip Good Governance pada Kinerja Keuangan LPD di Kabupaten Karangasem
}

\author{
Luh Ade Kusuma Yanti ${ }^{1}$ \\ Fakultas Ekonomi dan Bisnis \\ Universitas Udayana, Indonesia \\ Email: luhadekusumayanti@gmail.com
}

\author{
I Gde Ary Wirajaya ${ }^{2}$ \\ Fakultas Ekonomi dan Bisnis \\ Universitas Udayana, Indonesia
}

\begin{abstract}
ABSTRAK
Tujuan penelitian ini adalah untuk mengetahui pengaruh prinsip-prinsip good governance pada kinerja keuangan LPD di Kabupaten Karangasem. Lokasi penelitian dilakukan pada LPD di Kabupaten Karangasem. Metode pengambilan sampel dengan teknik purposive sampling. Sampel yang diperoleh yaitu sebanyak 90 LPD. Kinerja keuangan diukur menggunakan laporan keuangan LPD dari tahun 2016-2018. Prinsip-prinsip good governance diukur menggunakan pernyataan dalam kuesioner yang disebarkan ke LPD yang menjadi sampel. Teknis analisis menggunakan analisis regresi linier berganda. Berdasarkan hasil pengujian diperoleh bahwa prinsip-prinsip good governance yaitu transparansi, akuntabilitas, responsibilitas, independensi, dan kewajaran berpengaruh positif pada kinerja keuangan LPD di Kabupaten Karangasem.
\end{abstract}

Kata Kunci: Good Governance; Kinerja Keuangan; Lembaga Perkreditan Desa.

\section{The Effect of Good Governance Principles on LPD Financial Performance in Karangasem Regency}

\section{ABSTRACT}

The purpose of this study was to determine the effect of the principles of good governance on LPD financial performance in Karangasem Regency. The location of the study was conducted at the LPD in Karangasem Regency. The sampling method is purposive sampling technique. Samples obtained were as many as 90 LPD. Financial performance is measured using LPD financial statements from 20162018. Good governance principles are measured using statements in the questionnaire distributed to the sample LPD. Technical analysis uses multiple linear regression analysis. Based on the test results obtained that the principles of good governance, namely transparency, accountability, responsibility, independence, and reasonableness have a positive effect on LPD financial performance in Karangasem Regency.

Keywords: Good Governance; Financial Performance; Village Credit Institutions.

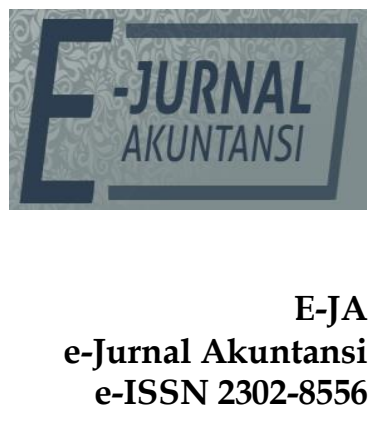

Vol. 30 No. 3

Denpasar, Maret 2020

Hal. 713-724

Artikel Masuk:

5 Desember 2019

Tanggal Diterima: 21 Januari 2020 


\section{PENDAHULUAN}

Lembaga Perkreditan Desa (LPD) dalam menjalankan fungsi usahanya secara umum dapat dikatakan berhasil mengelola organisasi usahanya dengan baik, namun tidak dapat dipungkiri masih banyak LPD yang dalam kondisi bermasalah bahkan tidak sedikit LPD yang mengalami kebangkrutan. Pada tahun 2016 tercatat terdapat 1.433 LPD yang ada di Bali. Dari data yang paparkan oleh Ketua Pansus LPD DPRD Provinsi Bali, dari total jumlah LPD tersebut sebanyak 158 LPD (11,03 persen) justru dinyatakan bangkrut karena sudah tidak beroperasi lagi (Bali Tribune, 2017).

Salah satu kasus yang terjadi di Desa Pekraman Sega, Kecamatan Abang, Kabupaten Karangasem. Menurut berita dari (NusaBali.com, 2018), ketua LPD Desa Adat Sega diduga korupsi uang nasabah. Pelaku membuat laporan fiktif dengan menyebutkan bahwa LPD tersebut memperoleh keuntungan, namun kenyataannya LPD tersebut mengalami kerugian. Kasus tersebut mulai diketahui semenjak dana nasabah macet sejak tahun 2010 serta tabungan dan deposito milik nasabah tidak bisa dicairkan. Hal ini membuktikan bahwa kinerja keuangan LPD di daerah tersebut tidak bagus.

Kinerja keuangan penting untuk dilakukan dalam sebuah usaha. Pengelolaan modal yang efektif dan efisien akan menjadi penentu keberhasilan dalam memperkuat cadangan modal baik tujuan memperkuat likuiditas maupun sebagai cadangan yang diperlukan untuk menghadapi risiko kerugian sebagai akibat dari kredit macet tak tertagih serta risiko bisnis lainnya (Budiasa et al., 2016). Menurut (Yazdanfar, 2013) kemampuan perusahaan dalam memperoleh laba akan menggambarkan efektivitas pengelolaan perusahaan. Tingkat profitabilitas digunakan dalam penelitian ini sebagai alat untuk mengukur kinerja keuangan.

Brigham \& Houston (2013:146) juga mengemukakan dalam mengukur profitabilias suatu perusahaan, di gunakan rasio profitabilitas karena rasio profitabilitas sudah mencakup rasio utang, rasio aktivitas maupun rasio likuiditas. Rasio profitabilitas terdiri dari enam rasio yaitu gross profit margin (GPM), net profit margin (NPM), operating return on assets (OPROA), return on asset (ROA), return on investment (ROI), return on equity (ROE), dan operating ratio (OPR). ROA adalah salah satu rasio keuangan yang digunakan untuk mengukur profitabilitas perusahaan secara menyeluruh. ROA merupakan rasio keuangan yang paling baik digunakan untuk mengukur kinerja keuangan. ROA berfokus terhadap kemampuan perusahaan untuk memperoleh laba dalam operasinya (Sudiyatno \& Suroso, 2010). Menurut Setyawan \& Putri (2013), keuntungan menggunakan ROA adalah pengukuran yang komperhensif dimana semua yang mempengaruhi laporan keuangan dapat tercermin.

Banyak faktor yang dapat digunakan untuk meningkatkan kinerja keuangan. Faktor-faktor tersebut seperti gaya kepemimpinan, kepuasan kerja serta good governance yang baik. Good governace semakin dipahami oleh kalangan pembuat kebijakan sebagai nilai untuk meningkatkan strategi bersaing perusahaan (Akinkoye, \& Olasanmi, 2014). Menurut Yahya \& Shukeri (2014) penerapan prinsip-prinsip good governance memiliki hubungan yang kuat dengan kinerja keuangan perusahaan. Perusahaan membutuhkan tata kelola organisasi usaha yang baik atau yang lebih dikenal dengan good governance (GG). Sistem 
good governance yang efektif memberikan pengaruh pada probabilitas perusahaan (Bistrova \& Lace, 2012). Ahmad Yaghoobnezhad et al., (2012) menyatakan bahwa tingkat good governance merupakan faktor penentu yang signifikan bagi kualitas laba perusahaan. Perusahaan yang menerapkan praktik good governance pada umumnya dapat meningkatkan modal perusahaannya lebih mudah dan dalam jangka panjang akan lebih menguntungkan serta kompetitif dibandingkan perusahaan yang memiliki tata kelola perusahaan yang buruk (Todorovic, 2013). Kualitas tata kelola perusahaan adalah kondisi yang diperlukan untuk menjamin dan memelihara kepercayaan pemangku kepentingan (Fathi, 2013). Menurut Komite Nasional Kebijakan Governance (2006) prinsip-prinsip good governance meliputi transparansi (transparency), prinsip akuntabilitas (accountability), prinsip responsibilitas (responsibility), prinsip independensi (independency), dan prinsip kewajaran (fairness). Kelima prinsip tersebut diharapkan dapat menghasilkan keputusan yang lebih optimal, jika tata kelola perusahaan baik maka menunjukkan tanggung jawab perusahaan yang lebih besar (Rambo, 2013). (Haque et al., (2008) menyatakan apabila dalam organisasi menerapkan prinsip transpransi ini, maka para stakeholder akan mempunyai kepercayaan terhadap organisasi tersebut sehingga akan lebih baik. Setyawan \& Putri (2013) menjelaskan bahwa penerapan prinsip-prinsip good governance diharapkan nantinya akan membantu LPD ke arah yang lebih baik, mampu bersaing dengan lembaga keuangan lain seperti bank dan dapat dikelola secara dinamis dan profesional sehingga dapat menjadi pesaing yang tangguh yang akhirnya akan memberikan kepercayaan terhadap nasabahnya.

LPD yang akan menjadi lokasi penelitian adalah LPD yang berada di Kabupaten Karangasem. Pemilihan Kabupaten Karangasem sebagai lokasi penelitian adalah karena kabupaten ini merupakan kabupaten yang sedang menggalakan pembangunan termasuk dalam bidang ekonomi sehingga Kabupaten Karangasem sangat mengharapkan adanya perkembangan pada LPD. Adapun tingkat kesehatan LPD di Kabupaten Karangasem disajikan pada Tabel 1.

Tabel Klasifikasi Kesehatan LPD di Kabupaten Karangasem Tahun 2016-2018

\begin{tabular}{llll}
\hline Uraian & 2016 & 2017 & 2018 \\
\hline Jumlah LPD & 190 & 190 & 190 \\
\hline Klasifikasi Kesehatan & & & \\
- Sehat & 112 & 95 & 90 \\
- Cukup Sehat & 37 & 50 & 43 \\
- Kurang Sehat & 17 & 15 & 15 \\
- Tidak Sehat & 0 & 6 & 6 \\
- Tidak Operasi & 24 & 24 & 36
\end{tabular}

Sumber: LPLPD Kabupaten Karangasem, 2019.

Berdasarkan Tabel 1. jumlah LPD di Kabupaten Karangasem menurut LPLPD Karangasem tahun 2016-2018 adalah sebanyak 190 LPD. Dari data yang diperoleh, LPD di Kabupaten Karangasem mengalami penurunan dari tahun 2016 sampai tahun 2018. Hal ini membuktikan bahwa beberapa LPD di Kabupaten Karangasem masih belum berjalan secara optimal sehingga mengakibatkan LPD tidak beroperasi kembali. 
Penelitian ini dilakukan atas dasar dimana terdapat permasalahan LPD yang ada di Bali dan hasil penelitian terdahulu yang tidak konsisten antara pengaruh prinsip - prinsip good governance dengan kinerja keuangan. Teori harapan beranggapan kekuatan dari kecenderungan untuk bertindak dengan cara tertentu bergantung pada kekuatan pengharapan bahwa tindakan itu akan diikuti oleh output tertentu dan tergantung pada daya tarik output tersebut bagi individu itu sendiri (Robbins \& Judge, 2013). Bulandari \& Damayanthi (2015) mendapatkan hasil bahwa prinsip keterbukaan, akuntabilitas, pertanggungjawaban, independensi dan kewajaran berpengaruh positif terhadap kinerja keuangan LPD di Kabupaten Badung. Hasil yang sama juga didapatkan oleh Sandraningsih \& Putri (2015) mendapatkan hasil bahwa prinsip-prinsip good governance berpengaruh positif terhadap kinerja keuangan LPD di Kecamatan Abiansemal. Namun, terdapat penelitian dengan hasil yang berbeda yang dilakukan oleh Sastra \& Erawati (2017) yang mendapatkan hasil bahwa hanya prinsip transparansi dan akuntabilitas yang berpengaruh positif terhadap kinerja keuangan. Namun, prinsip responsibilitas, independensi dan kewajaran tidak berpengaruh signifikan terhadap kinerja keuangan. Penelitian yang dilakukan oleh Putri \& Putra (2017) memperoleh hasil bahwa prinsip akuntabilitas dan independensi berpengaruh positif pada kinerja keuangan sedangkan prinsip transparansi, responsibilitas, dan kewajaran tidak berpengaruh terhadap kinerja keuangan.

Rahmatika et al., (2015) yang menyatakan bahwa penerapan salah satu prinsip GG yaitu transparancy berpengaruh positif terhadap kinerja keuangan PT. Angkasa Pura II. Hal tersebut sejalan dengan penelitian yang dilakukan oleh Andreana \& Wirajaya (2018), Pradnyaswari \& Putri (2016), dan Sastra \& Erawati (2017) yang menyatakan bahwa prinsip transparansi berpengaruh positif terhadap kinerja keuangan. Transparansi adalah salah satu prinsip good dovernance yang memiliki makna bahwa semua informasi di dalam perusahaan harus terbuka kepada stakeholder dengan pertimbangan bahwa stakeholder memiliki hak untuk mengetahui secara terbuka atas pertanggungjawaban LPD dalam pengelolaan seumber daya yang dipercayakan kepadanya. Apabila pengelola LPD menjalankan prinsip transparansi dengan baik, maka kinerja keuangan juga akan meningkat.

$\mathrm{H}_{1}$ : Prinsip transparansi (transparency) berpengaruh positif pada kinerja keuangan Lembaga Perkreditan Desa di Kabupaten Karangasem.

Rahmatika et al., (2015) mendapati hasil bahwa penerapan salah satu prinsip GCG yaitu accountability berpengaruh positif terhadap kinerja keuangan PT. Angkasa Pura II (Persero). Menurut Bulandari \& Damayanthi (2015) menyatakan bahwa prinsip akuntabilitas berpengaruh positif terhadap kinerja keuangan LPD di Kabupaten Badung. Akuntabilitas adalah pertanggungjawaban pengurus LPD atas kinerjanya secara transparan dan wajar kepada anggota LPD serta memiliki kejelasan mengenai wewenang serta fungsi pelaksanaan struktur organisasi yang sudah ada. Untuk itu perusahaan harus dikelola secara benar yang pada akhirnya akan meningkatkan kinerja keuangan LPD.

$\mathrm{H}_{2}$ : Prinsip akuntabilitas (accountability) berpengaruh positif pada kinerja keuangan Lembaga Perkreditan Desa di Kabupaten Karangasem. 
Hasil penelitian Hindistari \& Putri (2016), menjelaskan prinsp responsibilitas berpengaruh positif terhadap kinerja BPR Kabupaten Gianyar. Hal tersebut sejalan dengan penelitian Rahmatika et al., (2015) menunjukkan hasil bahwa prinsip responsibilitas berpengaruh terhadap kinerja keuangan PT. Angkasa Pura II (Persero). Dengan perusahaan mampu mematuhi peraturan dan tanggung jawabnya kepada stakeholders, maka hal tersebut dapat meningkatkan kinerja perusahaan. Prinsip responsibilitas (responsibility) adalah sikap pengelola LPD dalam mengelola usahanya berdasarkan peraturan perundang-undangan yang berlaku. Untuk meningkatkan kinerjanya, pengelola LPD harus memahami dan mematuhi peraturan serta melaksanakan tanggung jawab sehingga dapat terpelihara kesinambungan usaha dalam jangka panjang dan akhirnyan dapat meningkatkan kinerja keuangan. Semakin baik pengelola LPD dalam menrapkan prinsip responsibilitas maka semakin baik pula kinerja keuangannya.

$\mathrm{H}_{3}$ : Prinsip responsibility (responsibility) berpengaruh positif pada kinerja keuangan Lembaga Perkreditan Desa di Kabupaten Karangasem.

Rahmatika et al., (2015) dalam penelitiannya menunjukan bahwa terdapat pengaruh positif dari penerapan kemandirian (indepedency) terhadap kinerja keuangan PT. Angkasa Pura II (Persero). Hasil yang sama juga di dapatkan oleh Bulandari \& Damayanthi (2015) dan Sastra \& Erawati (2017) yang menyatakan bahwa prinsip independensi berpengaruh positif pada kinerja keuangan.

Prinsip independensi adalah sikap pengurus LPD dalam mengambil keputusan tanpa terikat dengan pihak manapun atau pihak yang mendominasi. Untuk meningkatkan kinerjanya, karyawan dan manajer harus bersikap secara objektif atau bebas dari kepentingan pihak yang merugikan organisasi usaha tersebut sehingga nantinya dapat meningkatkan kinerja keuangan. Jadi, semakin manajemen LPD bersikap independen maka semakin baik pula kinerja keuangannya.

$\mathrm{H}_{4}$ : Prinsip independensi (independency) berpengaruh positif pada kinerja keungan Lembaga Perkreditan Desa di Kabupaten Karangasem.

Rahmatika et al., (2015) menyatakan pengaruh antara kewajaran terhadap kinerja keuangan menunjukan hasil positif, hal ini menunjukan bahwa kewajaran berpengaruh terhadap kinerja keuangan. Hasil penelitian ini menunjukan bahwa kewajaran berpengaruh terhadap kinerja keuangan. Organisasi bisnis seyogyanya dapat memperhatikan hak dari pemangku kepentingan berdasarkan atas kewajaran dan kesetaraan dalam rangka meningkatkan kinerja keuangan perusahaan. Kewajaran merupakan keadilan dan kesejahteraan dalam memenuhi hak-hak stakeholders yang timbul berdasarkan perjanjian dan perundang-undangan yang berlaku. Kewajaran merujuk pada keadilan dan kesetaraan dalam memenuhi hak-hak pemangku kepentingan yang timbul sebagai akibat dari perjanjian dan peraturan perundang-undangan yang berlaku. Proses pengambilan keputusan berdasarkan asas kewajaran ini akan menghasilkan keputusan yang adil bagi semua pihak yang berkepentingan terhadap LPD, sehingga tercipta iklim yang kondusif dalam organisasi yang berujung pada peningkatan kinerja keuangan LPD kearah yang lebih baik.

$\mathrm{H}_{5}$ : Prinsip kewajaran berpengaruh positif pada kinerja keuangan Lembaga Perkreditan Desa di Kabupaten Karangasem. 


\section{METODE PENELITIAN}

Lokasi penelitian adalah suatu tempat atau wilayah dimana penelitian tersebut akan dilakukan. Penelitian ini dilakukan pada LPD yang berada di Kabupaten Karangasem, Provinsi Bali. Kabupaten Karangasem terdapat sebanyak 190 LPD yang tersebar di 8 kecamatan. Populasi dalam penelitian ini adalah seluruh LPD yang berada di Kabupaten Karangasem, Provinsi Bali. Jumlah LPD yang berada di Kabupaten Karangasem adalah 190. Metode pengambilan sampel dalam penelitian ini adalah nonprobability sampling yaitu purposive sampling. Teknik purposive sampling yaitu menentukan ciri-ciri khusus yang sesuai dengan tujuan penelitian. Kriteria yang digunakan untuk penentuan sampel yaitu LPD yang tergolong sehat. Penarikan sampel pada LPD yang tergolong sehat karena sudah mampu mewakili seluruh populasi. Berdasarkan penjelasan tersebut, maka sampel dalam penelitian ini adalah sebanyak 90 LPD.

Analisis regresi linear berganda merupakan teknik statistik melalui koefisien parameter untuk mengetahui besarnya pengaruh variabel independen terhadap variabel dependen. Model persamaan regresi yang digunakan dalam penelitian ini diasumsikan linear dan diuji dengan tingkat signifikansi $a=0,05$ Adapun model persamaan analisis regresi penelitian ini adalah sebagai berikut:

$Y=\alpha+\beta_{1} X_{1}+\beta_{2} X_{2}+\beta_{3} X_{3}+e$

Keterangan:

$\mathrm{Y}=$ Kinerja Keuangan

$\alpha=$ Konstanta

$\beta_{1}, \beta_{2}, \beta_{3}=$ koefisien regresi

$\mathrm{X}_{1}=$ Variabel independen, yaitu transparansi

$\mathrm{X}_{2}=$ Variabel independen, yaitu akuntabilitas

$\mathrm{X}_{3}=$ Variabel independen, yaitu responsibilitas

$\mathrm{X}_{4}=$ Variabel independen, yaitu independensi

$\mathrm{X}_{5}=$ Variabel independen, yaitu kewajaran

$\mathrm{e}=$ Standard Error

\section{HASIL DAN PEMBAHASAN}

Uji $\mathrm{F}$ digunakan untuk menguji model yang digunakan apakah layak untuk dilanjutkan. Apabila dari uji $\mathrm{F}$ didapat probabilitas lebih kecil dari 0,5 berarti model yang digunakan layak untuk dilanjutkan. Hasil uji $\mathrm{F}$ penelitian ini disajikan pada Tabel 2.

\section{Tabel 2. Hasil Uji F}

\begin{tabular}{lllllll}
\hline Model & Sum of Squares & Df & Mean Square & F & Sig. \\
\hline 1 & Regression & 0,448 & 5 & 0,090 & 17,015 & $0,000^{\mathrm{a}}$ \\
& Residual & 0,915 & 174 & 0,005 & & \\
& Total & 1,363 & 179 & & & \\
\hline
\end{tabular}

Sumber: Data Penelitian, 2019

Berdasarkan hasil uji F pada Tabel 2. didapat bahwa hasil nilai $\mathrm{F}$ sebesar 17,015 dengan probabilitas 0,000, karena probabilitas < 0,05 maka model yang digunakan layak untuk dilanjutkan.

Koefisien determinasi $\left(R^{2}\right)$ pada intinya mengukur seberapa jauh kemampuan model dalam menerangkan variasi variabel dependen. Untuk 
melihat seberapa besar kontribusi variabel bebas mampu menjelaskan perubahan variabel terikatnya dapat dilihat pada nilai koefisien adjusted $R^{2}$ yang tertera pada Tabel 3.

Tabel 3. Hasil Uji Koefisien Determinasi

\begin{tabular}{lllll}
\hline Model & $\mathrm{R}$ & R Square & Ajusted R Square & $\begin{array}{l}\text { Std. Error of the } \\
\text { Estimate }\end{array}$ \\
\hline 1 & $0,573^{\mathrm{a}}$ & 0,328 & 0,309 & 0,072532 \\
\hline
\end{tabular}

Sumber: Data Penelitian, 2019

Berdasarkan hasil output analisis uji koefisien determinasi yang dinyatakan dalam Tabel 3. dapat dilihat nilai Adjusted $R^{2}$ yaitu sebesar 0,30, hal ini berarti $30 \%$ variasi kinerja keuangan dapat dijelaskan oleh variasi variabel bebas yaitu transparansi, akuntabilitas, responsibilitas, independensi, serta kewajaran. Sedangkan sisanya sebesar $70 \%$ dijelaskan oleh faktor lain diluar model.

Uji t digunakan untuk mengetahuipengaruh variabel bebas pada variabel terikat secara parsial. Dari hasil uji diperoleh data seperti pada Tabel 4.

Tabel 4. Hasil Uji t

\begin{tabular}{|c|c|c|c|c|c|}
\hline \multirow[t]{2}{*}{ Model } & \multicolumn{2}{|c|}{ Unstandardized Coefficients } & Standardized & $\mathrm{t}$ & Sig \\
\hline & B & Std. error & Beta & & \\
\hline (Constant) & $-0,675$ & 0,094 & & $-7,211$ & 0,000 \\
\hline $\mathrm{X} 1$ & 0,012 & 0,004 & 0,221 & 3,300 & 0,001 \\
\hline $\mathrm{X} 2$ & 0,005 & 0,002 & 0,188 & 2,836 & 0,005 \\
\hline $\mathrm{X} 3$ & 0,007 & 0,003 & 0,150 & 2,124 & 0,035 \\
\hline X4 & 0,013 & 0,004 & 0,223 & 3,458 & 0,001 \\
\hline X5 & 0,012 & 0,004 & 0,191 & 2,916 & 0,004 \\
\hline
\end{tabular}

Sumber: Data Penelitian, 2019

Tabel 4. menjelaskan bahwa hasil uji $\mathrm{t}$ menunjukkan nilai $\mathrm{t}$ hitung untuk variabel transparansi sebesar 3,300 dengan tingkat signifikansi 0,001 yang memmiliki nilai kurang dari 0,05 . Hal ini berarti bahwa prinsip transparansi berpengaruh positif pada kinerja LPD yang ada di Kabupaten Karangasem, sehingga hipotesis pertama diterima. Nilai t hitung untuk variabel akuntabilitas sebesar 2,836 dengan tingkat signifikansi 0,005 yang memiliki nilai kurang dari 0,05. Hal ini memiliki arti bahwa prinsip akuntabilitas berpengaruh positif pada kinerja LPD yang ada di Kabupaten Karangasem, sehingga hipotesis kedua diterima. Nilai $\mathrm{t}$ hitung untuk variabel responsibilitas sebesar 2,124 dengan tingkat signifikansi 0,035 yang memiliki nilai kurang dari 0,05. Hal ini memiliki arti bahwa prinsip responsibilitas berpengaruh positif pada kinerja LPD yang ada di Kabupaten Karangasem, sehingga hipotesis ketiga diterima. Nilai t hitung untuk variabel independensi sebesar 3,458 dengan tingkat signifikansi 0,001 yang memiliki arti kurang dari 0,05. Hal ini memiliki arti bahwa prinsip independensi berpengaruh positif pada kinerja LPD yanga ada di Kabupaten Karangasem, sehingga hipotesis keempat diterima. Nilai $t$ hitung untuk variabel kewajaran sebesar 2,916 dengan tingkat signifikansi 0,004 yang memiliki arti kurang dari 0,05 . Hal ini memiliki arti bahwa prinsip kewajaran berpengaruh positif pada kinerja LPD yang ada di Kabupaten Karangasem, sehingga hipotesis kelima diterima. 
Interpretasi dari persamaan regresi linier berganda dapat digunakan untuk menemukan persamaan dalam penelitian yang dilakukan yang dapat digunakan untuk menentukan model penelitian dan menjelaskan pengaruh masing-masing variabel bebas terhadap variabel terikat.

Adapun persamaan regresi linier berganda yang dapat dibentuk berdasarkan Tabel 4.

$$
Y=-0,675+0,012 X 1+0,005 X 2+0,007 X 3+0,013 X 4+0,012 X 5
$$

Berdasarkan model persamaan regresi tersebut dapat dijelaskan yaitu nilai koefisien regresi transparansi $\left(X_{1}\right)$ sebesar 0,012 memiliki arti bahwa apabila variabel transparansi mengalami peningkatan dalam penerapannya, maka kinerja keuangan akan meningkat dengan asumsi variabel bebas lainnya adalah konstan atau tidak mengalami perubahan. Nilai koefisien akuntabilitas $\left(X_{2}\right)$ sebesar 0,005 memiliki arti bahwa apabila variabel akuntabilitas mengalami peningkatan ketika penerapannya, maka kinerja keuangan akan meningkat pula dengan asumsi variabel bebas lainnya adalah konstan atau tidak mengalami perubahan. Nilai koefisien responsibilitas $\left(X_{3}\right)$ sebesar 0,007 memiliki arti apabila variabel responsibilitas penerapannya ditingkatkan, maka kinerja keuangan juga akan meningkat dengan asumsi variabel bebas lainnya adalah konstan atau tidak mengalami perubahan. Nilai koefisien independensi $\left(X_{4}\right)$ sebesar 0,013 memiliki arti bahwa apabila variabel independensi mengalami peningkatan dalam penerapannya, maka kinerja keuangan akan meningkat pula dengan asumsi variabel bebas lainnya adalah konstan atau tidak mengalami perubahan. Dan yang terakhir nilai koefisien kewajaran $\left(X_{5}\right)$ sebesar 0,012 mempunyai arti bahwa apabila variabel kewajaran penerapannya ditingkatkan, maka kinerja keuangan akan meningkat pula dengan asumsi variabel bebas lainnya adalah konstan atau tidak mengalami perubahan.

Berdasarkan hasil olahan SPSS yang termuat dalam Tabel 4, hasilnya menunjukkan bahwa variabel transparansi berpengaruh positif terhadap kinerja keuangan LPD di Kabupaten Karangasem. Hal ini ditunjukkan dengan nilai signifikansi sebesar 0,001 yang nilainya lebih kecil dari tingkat signifikan yang ditetapkan $(\alpha=0,05)$ sehingga hipotesis pertama $\left(\mathrm{H}_{1}\right)$ diterima yakni prinsip transparansi berpengaruh positif pada kinerja keuangan LPD di Kabupaten Karangasem. Hasil penelitian ini memperkuat hasil penelitian yang dilakukan oleh Pradnyaswari \& Putri (2016), Sastra \& Erawati (2017) dan Andreana \& Wirajaya (2018) yang menyatakan bahwa prinsip transparansi berpengaruh pada kinerja keuangan. Prinsip transparansi berpengaruh positif pada kinerja keuangan berarti semakin baik tingkat transparansi yang dilakukan dalam LPD maka semakin baik juga kinerja keuangannya. Sesuai dengan teori harapan, hal ini menunjukkan bahwa semakin transparan pengelola LPD dalam mengungkapkan informasi mengenai keadaan LPD maka semakin baik juga hasil kinerja keuangan yang diperolehnya.

Berdasarkan hasil olahan SPSS yang termuat dalam Tabel 4. hasilnya menunjukkan bahwa variabel akuntabilitas berpengaruh positif terhadap kinerja keuangan LPD di Kabupaten Karangasem. Hal ini ditunjukkan dengan nilai signifikansi sebesar 0,005 yang nilainya lebih kecil dari tingkat signifikan yang ditetapkan $(\alpha=0,05)$ sehingga hipotesis kedua $\left(\mathrm{H}_{2}\right)$ diterima yakni prinsip akuntabilitas berpengaruh positif pada kinerja keuangan LPD di Kabupaten 
Karangasem. Hasil penelitian ini mendukung penelitian yang dilakukan oleh Bulandari \& Damayanthi (2015), Rahmatika et al., (2015), serta Sastra \& Erawati (2017) yang menyatakan bahwa prinsip akuntabilitas berpengaruh pada kinerja keuangan. Prinsip akuntabilitas berpengaruh positif pada kinerja keuangan yang berarti semakin baik LPD menjalankan prinsip akuntabilitas maka semakin baik kinerja keuangan LPD tersebut. Sesuai dengan teori harapan, hal ini menunjukkan bahwa semakin jelas wewenang dan fungsi pelaksanaan serta pertanggungjawaban struktur organisasi dalam LPD maka output yang diperoleh dalam hal ini kinerja keuangan akan semakin baik.

Berdasarkan hasil olahan SPSS yang termuat dalam Tabel 4. hasilnya menunjukkan bahwa variabel responsibilitas berpengaruh positif terhadap kinerja keuangan LPD di Kabupaten Karangasem. Hal ini ditunjukkan dengan nilai signifikansi sebesar 0,035 yang nilainya lebih kecil dari tingkat signifikan yang ditetapkan $(\alpha=0,05)$ sehingga hipotesis ketiga $\left(\mathrm{H}_{3}\right)$ diterima yakni prinsip responsibilitas berpengaruh positif pada kinerja keuangan LPD di Kabupaten Karangasem. Hasil penelitian ini memperkuat hasil penelitian yang dilakukan oleh Bulandari \& Damayanthi (2015), Rahmatika \& Agusti (2015), dan Hindistari \& Putri (2016) yang menyatakan bahwa prinsip responsibilitas berpengaruh terhadap kinerja keuangan. Prinsip responsibilitas berpengaruh positif pada kinerja keuangan yang berarti semakin baik prinsip responsibilitas dijalankan maka semakin baik kinerja keuangannya. Sesuai dengan teori harapan, hal ini menunjukkan bahwa jika pengelola LPD memenuhi segala peraturan yang ada serta melaksanakan tanggungjawab terhadap prinsipal hal tersebut dapat meningkatkan kinerja keuangan LPD.

Berdasakan hasil olahan SPSS yang termuat dalam Tabel 4. hasilnya menunjukkan bahwa variabel independensi berpengaruh positif pada kinerja keuangan LPD di Kabupaten Karangasem. Hal ini ditunjukkan dengan nilai signifikan sebesar 0,001 yang nilainya lebih kecil dari tingkat signifikan yang ditetapkan $(\alpha=0,05)$ sehingga hipotesis keempat $\left(\mathrm{H}_{4}\right)$ diterima yakni prinsip independensi berpengaruh positif pada kinerja keuangan LPD di Kabupaten Karangsem. Hasil penelitian ini mendukung hasil penelitian yang dilakukan oleh Bulandari \& Damayanthi (2015), Sastra \& Erawati (2017), dan Andreana \& Wirajaya (2018) yang menyatakan bahwa prinsip independensi berpengaruh pada kinerja keuangan. Prinsip independensi berpengaruh positif pada kinerja keuangan yang berarti semakin baik LPD menjalankan prinsip independensi maka semakin baik hasil kinerja keuangan LPD. Sesuai dengan teori harapan, hal ini menunjukkan jika pengelola termotivasi dan mampu bersikap independen atau tidak terpengaruh dari pihak luar maka dapat dipastikan kinerja keuangannya dapat meningkat.

Berdasarkan hasil olahan SPSS yang termuat dalam Tabel 4. hasilnya menunjukkan bahwa variabel kewajaran berpengaruh positif pada kinerja keuangan LPD di Kabupaten Karangasem. Hal ini ditunjukkan dengan nilai signifikansi sebesar 0,004 yang nilainya sama dengan tingkat signifikan yang ditetapkan $(a=0,05)$ sehingga hipotesis kelima $\left(\mathrm{H}_{5}\right)$ diterima yakni prinsip kewajaran berpengaruh positif pada kinerja keuangan LPD di Kabupaten Karangasem. Hasil penelitian ini mendukung hasil penelitian yang dilakukan oleh Pradnyaswari \& Putri (2016), Rahmatika \& Agusti (2015) dan Bulandari \& 
Damayanthi (2015) yang menyatakan bahwa prinsip kewajaran berpengaruh positif pada kinerja keuangan. Prinsip kewajaran berpengaruh positif pada kinerja keuangan yang berarti semakin baik prinsip kewajaran dilaksanakan maka akan dapat meningkatkan kinerja keuangan. Sesuai dengan teori harapan, hal ini menunjukkan apabila pengelola LPD memperhatikan hak dari prinsipal serta memperlakukannya secara adil berdasarkan asas kewajaran dan kesetaraan maka dapat meningkatkan kinerja keuangan LPD.

\section{SIMPULAN}

Hasil penelitian ini menjelaskan bahwa teori yang digunakan dan teori tersebut masih sesuai dengan keadaan saat ini. Terdapat bukti empiris yang diperoleh melalui penelitian ini yaitu prinsip transparansi, akuntabilitas, independensi, responsibilitas, dan kewajaran berpengaruh positif pada kinerja keuangan LPD yang ada di Kabupaten Karangasem. Hal ini berarti semakin meningkatnya penerapan prinsip transparansi, akuntabilitas, responsibilitas, independensi, dan kewajaran dalam sebuah LPD semakin meningkat pula kinerja keuangan LPD tersebut. Hasil penelitian ini dapat menjadi pertimbangan hasil bagi pengelola LPD untuk mempertimbangkan penerapan prinsip-prinsip good governance yaitu transparansi, akuntabilitas, responsibilitas, independensi, dan kewajaran dalam mengelola LPD. Hal ini dapat dilakukan melalui publikasi laporan keuangan secara transparan, memberi kejelasan struktur dan wewenang dalam pengelolaan LPD, mentaati undang-undang yang berlaku, pengambilan keputusan dalam LPD tidak dipengaruhi oleh pihak lain, dan memperlakukan stakeholder secara adil. Dengan penerapan kelima prinsip tersebut dapat meningkatkan kepercayaan nasabah dan masyarakat desa adat nantinya berdampak pada peningkatan kinerja keuangan LPD.

\section{REFERENSI}

Ahmad Yaghoobnezhad. (2012). The investigation of the relationship between corporate governance and earnings quality. African Journal of Business Management. https://doi.org/10.5897/ajbm10.1291

Akinkoye, E. Y., and Olasanmi, O. O. (2014). Corporate governance practice and level of compliance among firms in nigeria: Industry analysis. Journal of Business and Retail Management Research, 9(1), 9(1). https://doi.org/10.12691/jbms-7-1-5

Andreana, M. O. C., \& Wirajaya, I. G. A. (2018). Pengaruh Transparancy, Accountability, Responsibility, Independency, dan Fairness Pada Kinerja Keuangan Lembaga Perkreditan Desa. E-Jurnal Akuntansi. https:// doi.org/10.24843/eja.2018.v23.i02.p19

Bali Tribune. (2017). 150 LPD di Bali Dinyatakan Bangkrut. Retrieved from https:// balitribune.co.id/content/150-lpd-di-bali-dinyatakan-bangkrut

Bistrova, J., \& Lace, N. (2012). Corporate Governance Influence on Firms' Financial Performance in CEE Countries. https://doi.org/10.3846/ bm.2012.002

Brigham, E. F., \& Houston, J. F. (2013). Dasar-Dasar Manajemen Keuangan. In Salemba Empat. https://doi.org/10.1145/2505515.2507827

Budiasa, I. K., Bagus, I., Purbawangsa, A., \& Rahyuda, H. (2016). Pengaruh Risiko Usaha Dan Struktur Modal Terhadap Pertumbuhan Aset Serta 
Profitabilitas Pada Lembaga Perkreditan Desa Di Kabupaten Badung. EJurnal Akuntansi Universitas Udayana 5.7, 7, 1919-1952.

Bulandari, I., \& Damayanthi, I. (2015). Pengaruh Prinsip-Prinsip Good Corporate Governance Pada Kinerja Keuangan Lembaga Perkreditan Desa Di Kabupaten Badung. E-Jurnal Akuntansi, 8(3), 630-648.

Fathi, J. (2013). The determinants of the quality of financial information disclosed by French listed companies. Mediterranean Journal of Social Sciences. https://doi.org/10.5901/mjss.2013.v4n2p319

Haque, F., Arun, T., \& Kirkpatrick, C. (2008). Corporate governance and capital markets: A conceptual framework. Corporate Ownership and Control, 5(2 C CONT. 2), 264-276. https:// doi.org/10.22495/cocv5i2c2p3

Hindistari, R., \& Putri, I. G. A. M. A. . (2016). Pengaruh Penerapan PrinsipPrinsip Good Corporate Governance Pada Kinerja Bank Perkreditan Rakyat Kabupaten Gianyar. E-Jurnal Akuntansi, 16(1), 101-128.

Komite Nasional Kebijakan Governance. (2006). Pedoman Umum Good Corporate Governance Indonesia. Jakarta.

NusaBali.com. (2018). Korupsi Rp. 548 Juta, Ketua LPD Ditahan. 2018. Retrieved from https://www.nusabali.com/berita/37720/korupsi-rp-548-juta-ketualpd-ditahan

Pradnyaswari, L., \& Putri, I. G. A. M. . A. D. (2016). Pengaruh Prinsip-Prinsip Good Corporate Governance Pada Kinerja Keuangan Koperasi Di Kabupaten Klungkung. E-Jurnal Akuntansi, 14(2), 1064-1091.

Putri, N. K. D. Y., \& Putra, I. M. P. D. (2017). Pengaruh Prinsip-Prinsip Good Corporate Governance, Motivasi, dan Budaya Organisasi Terhadap Kinerja Karyawan. E-Jurnal Akuntansi Universitas Udayana, 21, 1660-1688.

Rahmatika, N., \& Agusti, R. (2015). Pengaruh Penerapan Prinsip-Prinsip Good Corporate Governance Terhadap Kinerja Keuangan Perusahaan (Studi pada PT Angkasa Pura II). Jurnal Akuntansi. Retrieved from https:// docplayer.info/34423271-Pengaruh-penerapan-prinsip-prinsipgood-corporate-governance-terhadap-kinerja-keuangan-perusahaan-studipada-pt-angkasa-pura-ii.html

Rahmatika, N., Kirmizi, \& Agusti, R. (2015). Pengaruh Penerapan Prinsip-Prinsip Good Corporate Governance Terhadap Kinerja Keuangan Perusahaan (Studi pada PT Angkasa Pura II). Jurnal Akuntansi, 3(2), 148-159.

Rambo, C. M. (2013). Influence of the capital markets authority's corporate governance guidelines on financial performance of commercial banks in Kenya. International Journal of Business and Finance Research.

Robbins, S. P., \& Judge, T. A. (2013). Organizational Behavior 15th Edition. In Prentice Hall. https:// doi.org/10.12737/4477

Sandraningsih, K., \& Putri, I. G. A. M. A. . (2015). Pengaruh Prinsip-Prinsip Good Corporate Governance Pada Kinerja Keuangan Lembaga Perkreditan Desa Kecamatan Abiansemal. E-Jurnal Akuntansi, 11(3), 878-893.

Sastra, I. M. B., \& Erawati, N. M. A. (2017). Pengaruh Penerapan Prinsip-Prinsip Good Corporate Governance Dan Budaya Tri Hita Karana Pada Kinerja Keuangan. E-Jurnal Akuntansi Universitas Udayana, 19(1), 421-451.

Setyawan, Komanutri, \& Putri, I. G. A. M. A. D. (2013). Pengaruh Good Corporate Governance Terhadap Kinerja Keuangan Lembaga Pekreditan 
Desa Di Kecamatan Mengwi Kabupaten Badung. E-Jurnal Akuntansi, 5(3), 586-598.

Sudiyatno, B., \& Suroso, J. (2010). Analisis pengaruh DPK, BOPO, CAR dan LDR terhadap kinerja keuangan pada sektor perbankan yang go public di Bursa Efek Indonesia (BEI). Dinamika Keuangan Dan Perbankan.

Todorovic, I. (2013). Impact Of Corporate Governance On Performance Of Companies. Montenegrin Journal of Economics, 9(2), 47-54.

Yahya, A. S. B., \& Shukeri, S. N. (2014). Corporate governance and firm financial performance for Malaysian public listed company. Advances in Environmental Biology.

Yazdanfar, D. (2013). Profitability determinants among micro firms: Evidence from Swedish data. International Journal of Managerial Finance. https:// doi.org/10.1108/17439131311307565 